\title{
A Preliminary Study on Insect Pollinators in Apple Crop in Different Geographical Zones of Himachal Pradesh
}

\author{
Preeti Kaundil" and Raj Kumar Thakur \\ Department of Entomology, Dr. Y. S. Parmar University of Horticulture and Forestry, \\ Nauni, Solan India \\ *Corresponding author
}

\begin{abstract}
A B S T R A C T
Keywords

Pollination,

Pollinators,

Diversity, Apple,

Himachal Pradesh

Article Info

Accepted:

04 October 2020

Available Online:

10 November 2020

Pollination is a critical mechanism that promotes the yield of many crops in our environment. The pollination process primarily includes banks of animal pollinators, of which the insect population forms a major part. Studies on diversity of various insect visitors to apple crop was made by collecting the flower visitors in different orchards located at Nauni (Solan), Mashobra (Shimla) and Seobagh (Kullu) in the year 2018-2019. Insect diversity studies showed that apple flowers were visited by 34 species of insects belonging to 5 orders and 11 families of class insect. Of these, 13 species belonged to Hymenoptera, 12 from Diptera, 5 from Lepidoptera, 3 from Coleoptera and 1 to order Thysanoptera. Among the insects sampled by different methods, Apis mellifera, A. cerana and Episyrphus balteatus were most frequent visitors.
\end{abstract}

\section{Introduction}

Pollination is an important service of the regulation, promotion and cultural environment (Chagnon et al., 2015). It involves an integrated interaction framework that connects the vegetation of the earth, wildlife and human welfare (Kevan and Menzel, 2012). For the setting of fruits and seeds, many crops and wild plants need pollination. Pollination is the active and passive transfer within or between flowers of pollen (biologically speaking: transporting pollen from the output of anther to receiving the stigma of anthers).
Pollination offers an important ecosystem service that contributes to biodiversity conservation and ensures the survival of species of plant, including crops. One can thank a bee, butterfly, bat, bird or other pollinator for one out of every three bites eaten. Any loss of biodiversity is a matter of public concern, but the loss of pollinating insects can be particularly disturbing due to the potential impact on plant reproduction and, therefore, on food security. Many crops and populations of natural plants rely on pollination and often on the facilities provided by wild, unmanaged, pollinating communities (Free, 1993; Kluser and Peduzzi, 2007). Most 
pollination-contributing insects fall under three orders, i.e. Lepidoptera, Hymenoptera and Diptera (Jadhav et al., 2018; Bahir et al., 2018).

In recent years, the apple has emerged in the Himalayan belt as the leading cash crop amongst temperate fruit crops. It alone accounts for 48 per cent of all fruit areas and 78 per cent of overall production of fruit. During this time, the area covered by apple production increased from 35,076 ha in 197576 to 99,564 ha in 2009- 10 , showing an annual growth of 3.14 per cent (Singh et al., 2012).

The yield of apples per hectare has decreased over the last few years, despite a rise in the area under apple cultivation. Therefore, modified strategies are needed and other potential inputs need to be looked for, such as maximum use of under used and environmentally friendly tools, such as bee pollination to increase state apple production (Verma and Jindal, 1997; Mattu et al., 2012b; Mattu and Mattu, 2013; Mattu, 2014). Therefore, honey bees in apple orchards are also very effective pollinating insects and are the majority of pollinating insects (Free, 1993; Sharma et al., 2000). In addition, only managed insects for orchard pollination are available.

\section{Materials and Methods}

Studies on diversity of various insect visitors to apple crop was made by collecting the flower visitors in different orchards located at Solan (Nauni), Shimla (Mashobra) and Kullu (Seobagh). These apple orchards had more than 200 trees belonging to Golden delicious, Red delicious, Royal delicious, Super chief, Redvelox, Redlum gala and Red Gold varieties. Almost equal numbers of working hours were spent in each orchard. Moreover, these collections were conducting during the year 2018-2019 from different geographical zones of Himachal Pradesh. For collection, the insect pollinators were collected by different sampling methods (Fluorescent pan trap, Sweeping method and Aerial netting method) (Figure 1).

\section{Results and Discussion}

The diversity of insect pollinators visiting apple flowers from different geographical zones of Himachal Pradesh during 2019 were collected by different sampling methods (Fluorescent pan trap, Sweeping method and Aerial netting method). A total number of 34 insects belonging to 5 orders and 11 families of class insecta. Of these, 13 species belonged to Hymenoptera, 12 from Diptera, 5 from Lepidoptera, 3 from Coleoptera and 1 to order Thysanoptera. Hymenopterans visitors belonged to four families namely Apidae, Halictidae, Vespidae and Ichneumonidae. Hymenopterans were represented by species like Apis mellifera, Apis cerana, Apis dorsata, Bombus haemorrhoidalis, Ceratina smaragdina, Xylocopa amethystine, Xylocopa violacea, Halictus sp., Polistes maculipennis, Vespa auraria, Vespa sp, Xanthopimla sp. Of the dipterans, species like Episyrphus balteatus, Sphaerophoria Indiana, Eupeodes sp., Metasyrphus confrater, Ischiodon scutellaris, Eristalis tenax, Melanostoma, Sepsid fly, Chrysomya megacephala and Musca sp. spread over families Syrphidae, Sepsidae, Calliphoridae and Muscidae. Moreover, 5 species of lepidopterans were spread over families like Pieridae and Nymphalidae. Order Coleoptera was represented by one family i.e. Coccinellidae. In addition, a single species of thrips belonging to order Thysanoptera was also recorded as pollinator of apple crop (Table 1). Among the insects sampled by different methods, Apis mellifera, A. cerana and Episyrphus balteatus were most frequent visitors (Figure 2). 
Table.1 Diversity of insect pollinators visiting apple flowers with their taxonomic status

\begin{tabular}{|c|c|c|}
\hline Order & Family & Scientific Name \\
\hline \multirow{13}{*}{ Hymenoptera } & Apidae & Apis mellifera Linnaeus \\
\hline & & Apis cerana Fabricius \\
\hline & & Apis dorsata Fabricius \\
\hline & & Bombus haemorrhoidalis Smith \\
\hline & & Ceratina smaragdina Smith \\
\hline & & Xylocopa amethystina (Fabricius) \\
\hline & & Xylocopa violacea \\
\hline & Halictidae & Halictus sp. \\
\hline & Vespidae & Polistes maculipennis \\
\hline & & Vespa auraria Smith \\
\hline & & Vespa sp. 1 \\
\hline & & Vespa sp. 2 \\
\hline & Ichneumonidae & Xanthopimla sp. \\
\hline \multirow[t]{12}{*}{ Diptera } & Syrphidae & Episyrphus balteatus (De geer) \\
\hline & & Sphaerophoria Indiana Bigot \\
\hline & & Eupeodes sp. \\
\hline & & Metasyrphus confrater (Wiedemann) \\
\hline & & Ischiodon scutellaris (Fabricius) \\
\hline & & Eristalis tenax (Linnaeus) \\
\hline & & Eristalis sp.1 \\
\hline & & Eristalis $\mathrm{sp} .2$ \\
\hline & & Melanostoma \\
\hline & Sepsidae & Sepsid fly \\
\hline & Calliphoridae & Chrysomya megacephala \\
\hline & Muscidae & Musca sp. \\
\hline \multirow[t]{5}{*}{ Lepidoptera } & Pieridae & Pieris candida \\
\hline & & Pieris brassicae (Linnaeus) \\
\hline & & Vanessa cardui \\
\hline & & Vanessa cashmirensis \\
\hline & & Colias erate \\
\hline \multirow[t]{3}{*}{ Coleoptera } & Coccinellidae & Coccinella septumpunctata \\
\hline & & Coccinella sp. 1 \\
\hline & & Coccinella sp. 2 \\
\hline Thysanoptera & Thripidae & Thrips sp. \\
\hline
\end{tabular}


Fig.1 Use of fluorescent pan trap for passive sampling
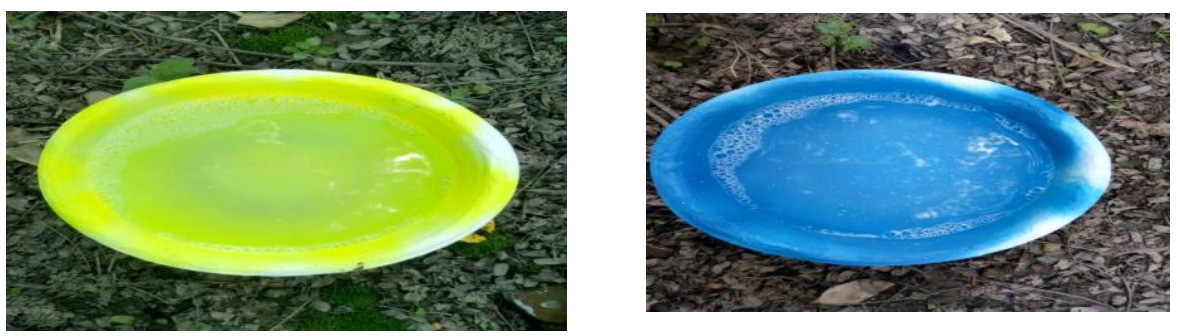

Fluorescent coloured traps (Yellow and blue)
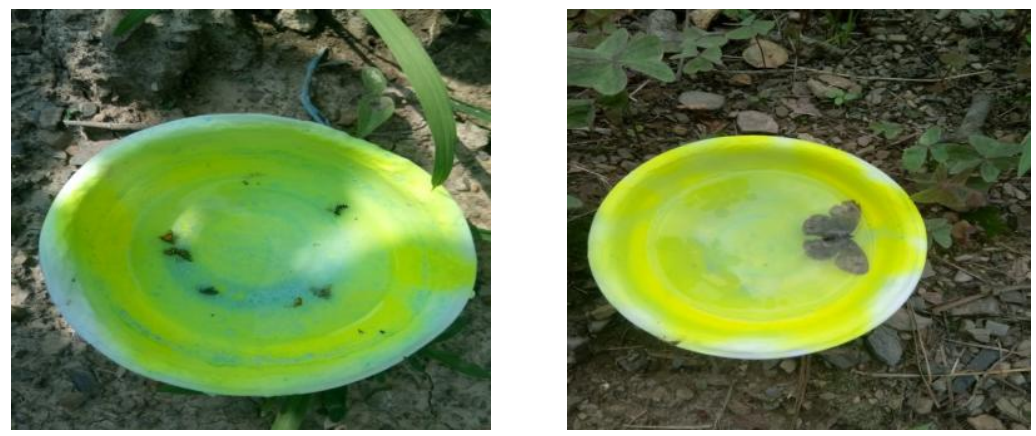

Insects caught in fluorescent trap

Fig.2 Important Hymenopteran and Dipteran insect visitors of apple flowers

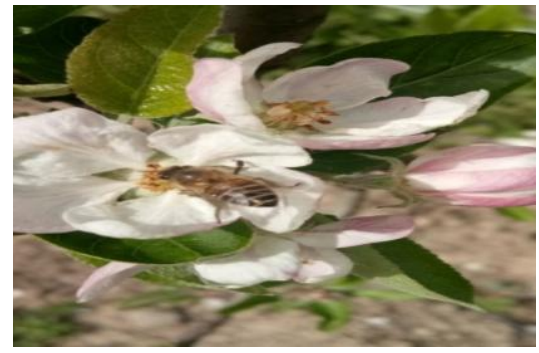

Apis cerana $\mathrm{F}$.

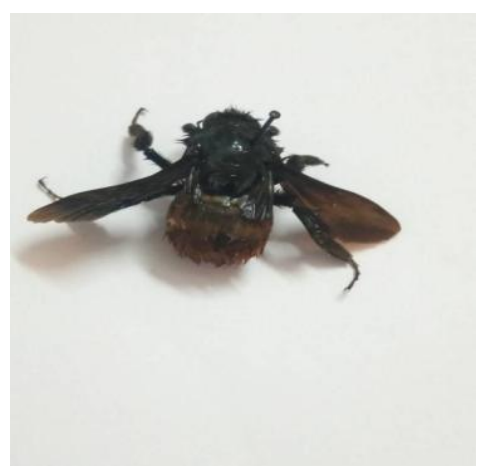

Bombus haemorrhoidalis

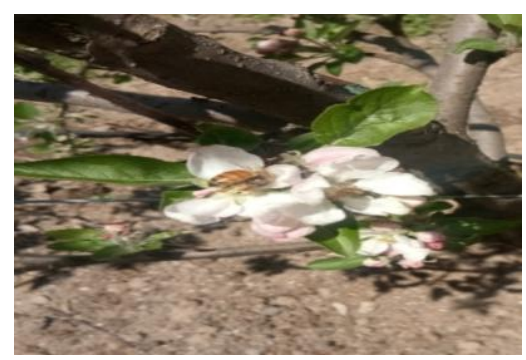

Apis mellifera L.

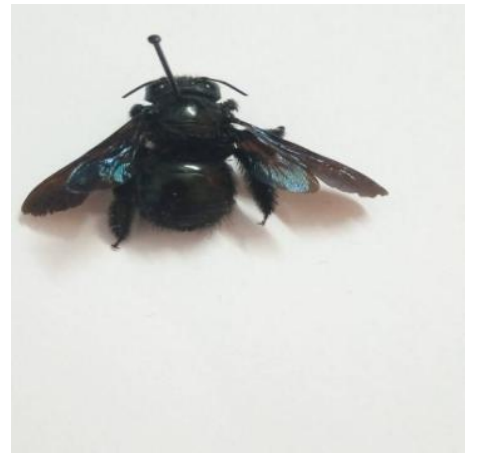

Xylocopa violacea 

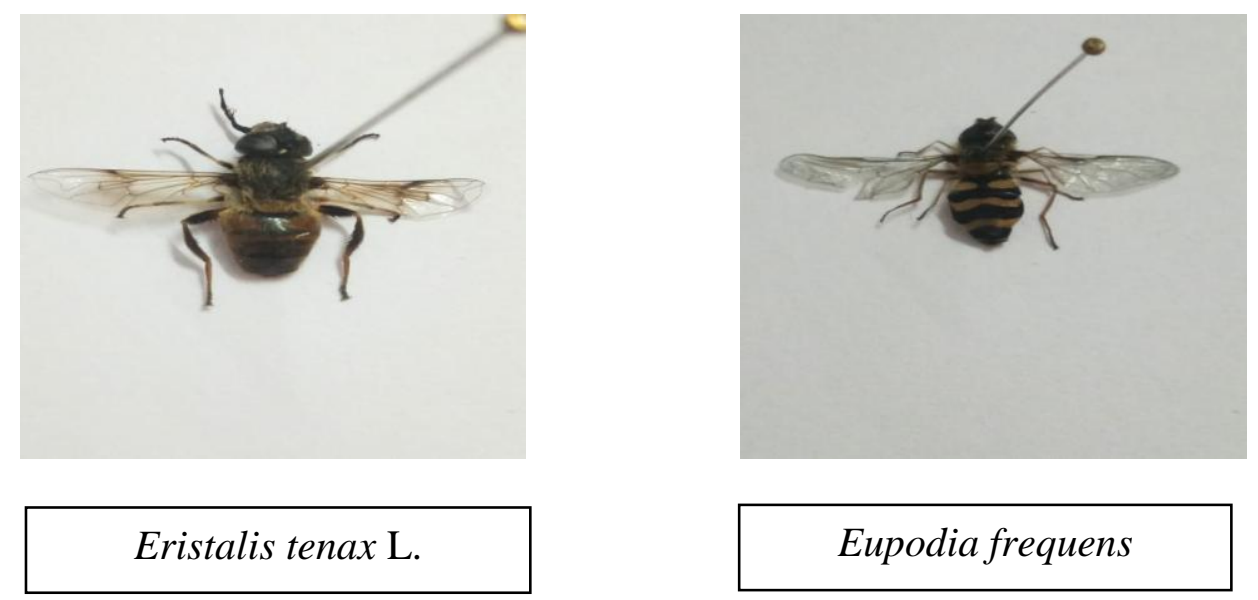

Eupodia frequens

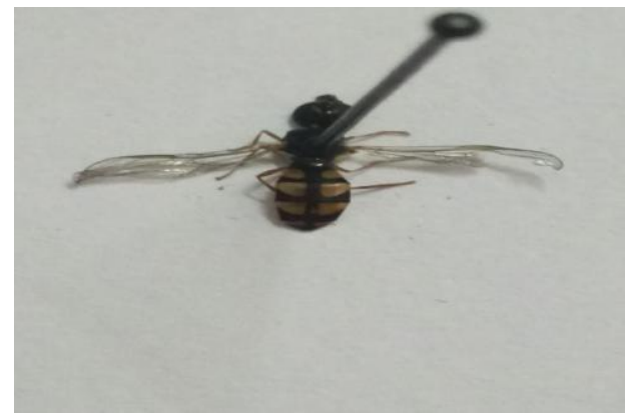

Melanostoma

Different investigators on different temperate fruit crops have reported different number of pollinators. For example, in Shimla hills, 44 species of insect pollinators were observed in Verma and Chauhan (1985), of which 16 belonged to Hymenoptera, 11 to Diptera, 9 to Lepidoptera, 7 to Coleoptera and 1 to Hemiptera on apple bloom. Hong et al., (1989) found a total of 88 species of pollinators on apple, pear and peach flowers in similar survey in North Korea, while Kumar (1997) recorded that 49 insect species in the Himalayan belt visited apple flowers.

Similarly, Thapa (2006) observed the presence in Nepal of 50 species of insect pollinators on flowers from different crops and found that honeybees accounted for 80 per cent of the overall pollination of insects. Pollinator diversity studies by Mattu et al., (2012a) and Raj et al., (2012) have also shown that 46 species of insects belonging to 5 orders and 17 families of class insecta have been visited by apple flowers.

It is proposed on the basis of current studies that hymenopterans and dipterans were the most abundant insect pollinators in apple bloom. Such findings confirm the findings of kumar (1995).

In conclusion the studies clearly show that the role of pollinators in increasing the fruit production in apple flowers is significant. As the populations of wild honey bees often fluctuate at various locations and between the years, adding hive bees to fruit orchards will ensure increased fruit production in apple crops. 


\section{Acknowledgements}

The authors are thank full to head of department and all teaching and non-teaching staff of Department of Entomology, UHF, Nauni (Solan).

\section{References}

Bashir, M. A., Saeed, S., Sajjad, A., Khan, K. A., Ghramh, H. A., Shehzad, M. A. and Ansari, M. J. (2018). Insect pollinator diversity in four forested ecosystems of southern Punjab, Pakistan. Saudi Journal of Biological Sciences.

Chagnon, M., Kreutzweiser D., Mitchell E., Morrissey C., Noome A and Van der Sluijs J. 2015. Risks of large-scale use of systemic insecticides to ecosystem functioning and services. Environmental Science and Pollution Research International., 22: 119-134.

Free, J. B. 1993. Insect Pollination of Crops. Academic Press, London, 684.

Hong, K. J., Lee, S. H. and Choi, K. M. 1989. Flower visiting insects on the flowers of pear, peach and apple trees in Suwon. Korean Journak of Apiculture., 4: 16-24.

Jadhav A., Kolla S. \& Prasad R. P. 2018. Insect pollinator diversity and abundance in sunflower ecosystem. Current Biotica., 5(3): 344-350.

Kevan, P. G., and Menzel, R. 2012. The plight of pollination and the interface of neurobiology, ecology and food security. The Environmentalist., 32: 300-310.

Klein, A. M., Vaissiere, B. E., Cane, J. H., Dewenter, I. S., Cunningham, S. A., Kremen, C. and Tscharntke, T. 2007. Importance of pollinators in changing landscapes for world crops. Proceedings of the Royal Society., 274: 303-313.
Kluser, S. and Peduzzi, P. 2007. Global Pollinator Decline: A Literature Review, UNEP/GRID Europe, UNEP.

Kumar, D. 1995. Bioecology of Apis and its mite pests in relation to almond and peach pollination, Ph.D. Thesis, Himachal Pradesh University, Shimla, India.

Kumar, L. 1997. Foraging ecology and behaviour of Apis cerana F. and Apis mellifera $\mathrm{L}$. in pollinating apple and cherry flowers. Ph.D Thesis, Himachal Pradesh University, Shimla, India.

Mattu, V. K. 2014. Role of honeybees and other pollinators in crop productivity and impacts of climate change. Workshop on Promotion of Honey Beekeeping in Haryana, Panchkula, pp. 56-74.

Mattu, V. K. and Mattu, N. 2013. Mountain perspectives and modern Beekeeping Technology. Himalayan Studies Journal., 4: 103-114.

Mattu, V. K., Hem Raj and Thakur, M. L. 2012b. Foraging behavior of honeybees on apple crop and its variation with altitude in Shimla Hills of Western Himalaya, India. International Journal of Science and Nature., 3(1): 296-301.

Mattu, V.K., Hem Raj and Mattu, N. 2012a. Pollinator diversity and relative abundance studies on apple crop in Shimla Hills, Himachal Pradesh. International Journal of Science and Nature., 1(2): 130-135.

Raj, H., Mattu, V. K. and Thakur, M. L. 2012. Pollinator diversity and relative abundance of insect visitors on apple crop in Shimla hills of western Himalaya, India. International Journal of Science and Nature., 3 (3): 507513.

Sharma, H. K., Gupta J. K and Thakur J. R. 2000. Pollination studies on apple and 
pear. In: Tropical bees: proceeding International Conference held at Chiang Mai, Thailand w.e.f 19-27 March, 2000.

Singh, R., Vaidya, C. S. and Saraswat, S .P. 2012. Impact of high density apple plantation under horticulture in Himachal Pradesh. Agro Economic Research Centre, H.P. University, Shimla, 114 pp.

Thapa, R. B. 2006. Honeybees and other insect pollinators of cultivated plants:
A review. Journal of the Institute of Agriculture and Animal Science., 27:1-23.

Verma, L. R. and Jindal, K. K. 1997. Fruit crops pollination. Kalyani Publishers, Ludhiana, India.

Verma, L.R. and Chauhan, P. 1985. Distribution, abundance and diversity of insect pollinators in apple orchards of Shimla hills. Indian Journal of Ecology., 12: 286-292.

\section{How to cite this article:}

Preeti Kaundil and Raj Kumar Thakur. 2020. A Preliminary Study on Insect Pollinators in Apple Crop in Different Geographical Zones of Himachal Pradesh. Int.J.Curr.Microbiol.App.Sci. 9(11): 325-331. doi: https://doi.org/10.20546/ijcmas.2020.911.039 